Plates of abdominal segments uniformly pigmented, without transparent dots

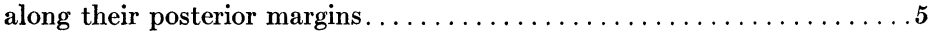

2. Front almost twice as broad behind as long. ...................

Front narrower in proportion to its length; three bristles on lateral margin of front above the antennal cavity.........................

3. Head viewed from the side twice as long as high.. .(Jamaica, B. W. I.)...... jamaicensis Brues.

Head viewed from the side only one-half longer than high. (Bismark Archipelago.).......................... dorsalis Wandolleck.

4. Thorax greatly constricted medially, its length at the sides over twice that at the middle. (Sumatra.)..................... depressus de Meijere.

Thorax less strongly constricted medially, much less than twice as long at the sides as at the middle. (German East Africa.).......kiboshoënsis Brues.

5. Lateral margin of front above antennal cavity with one or more bristles which are much larger than the sparse hairs covering the head ...........6

Lateral margin of front without any bristles above the antennal cavity; fourth dorsal plate of abdomen much longer than the third. (Guatemala.).......

buccata Malloch.

6. Lateral margin of front with a single bristle above the antennal cavity. (Mexico.).............................. mexicanus Silvestri.

Lateral margin of front with three bristles above the antennal cavity. (India.) fletcheri Schmitz.

\title{
AN OBSERVATION ON THE BREEDING HABITS OF STIGMUS CONESTOGORUM ROHWER.
}

\author{
By C. H. Richardson, \\ New Brunswick, New Jersey.
}

In a number of galls of Holcaspis globulus gathered from white oaks on September 13, 1914, at New Brunswick, N. J., was one inhabited by the wasp, Stigmus conestogorum. The dried condition of the gall showed that it had been deserted by the original owners. The wasp had formed numerous passage-ways in the pith which terminated in oval-shaped chambers. These chambers were filled with green aphids upon which larvæ, presumably of this species, were feeding. Since the female wasp was captured in the nest, it is possible that the larvæ of this species are attended by the parent throughout their active feeding period.

Stigmus fraternus and other Pemphredonidæ are said to burrow in the dried pithy branches of various kinds of plants and to fill 
their nests with plant lice. ${ }^{1}$ Perhaps S. conestogorum also normally makes its nest in such twigs and only occasionally accepts galls. In any case, it is not a far cry from pithy twigs to pithy cynipid galls.

This species is, I believe, here recorded for the first time from New Jersey. It was described from specimens obtained in Pennsylvania. $^{2}$ I am indebted to Mr. Rohwer for the identification of the New Jersey specimen.

\title{
NOTES ON THE OCCURRENCE OF SOME ECONOMIC INSECTS NOT HERETOFORE RECORDED FROM NEW JERSEY.
}

\author{
By Harry B. Weiss, \\ New Brunswick, New Jersey. \\ Gracilaria azaleæ Busck.
}

This species has been noted in several greenhouses in northern New Jersey. The small larvæ turn over the tips and edges of azalea leaves and feed therein causing them to turn black and die. Pupation takes place in a silken, whitish cocoon usually attached to the leaf near where the larva has been feeding. This insect has also been taken in the larval and pupal stages on azaleas imported into New Jersey from Belgium. As yet, it has not become a serious greenhouse pest, probably because azaleas as a rule are not carried over until the next season or grown by most florists. After being forced, practically all are sold and fresh ones imported the next year.

Kaliosysphinga ulmi Lund.

This saw-fly leaf miner was noted at Westfield, N. J., during the summer of 1914, doing noticeable but not serious damage to the foliage of elm trees. The mines were irregular and blotch like in appearance. In Smith's 1909 list, it is mentioned only as being sure to occur in New Jersey.

1 Comstock. Manual for the study of insects, ed. 1913, pp. 655-656.

2 Rohwer, Proc. U. S. Nat. Mus., Vol. 40, 1911, pp. 557-558. 

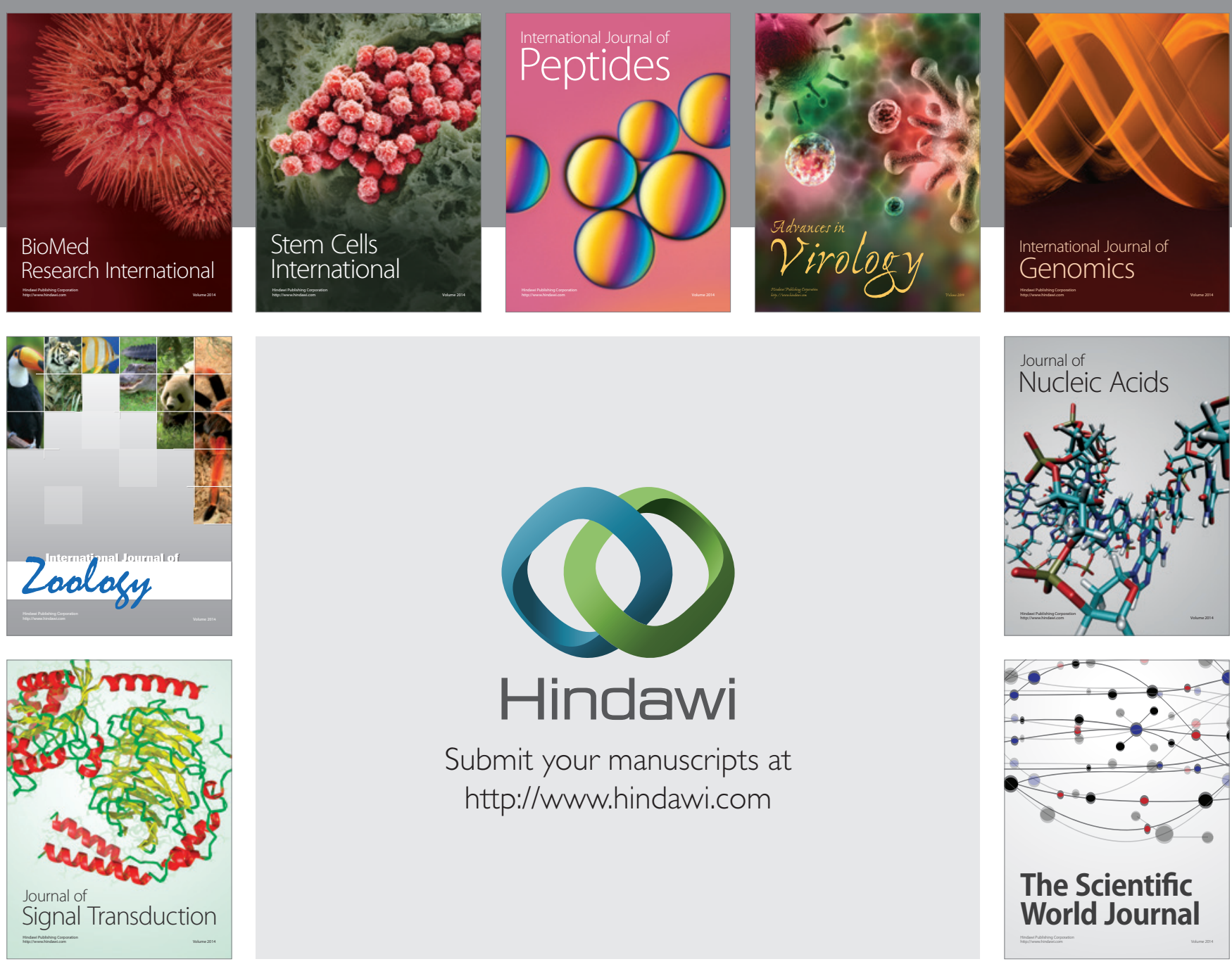

Submit your manuscripts at

http://www.hindawi.com
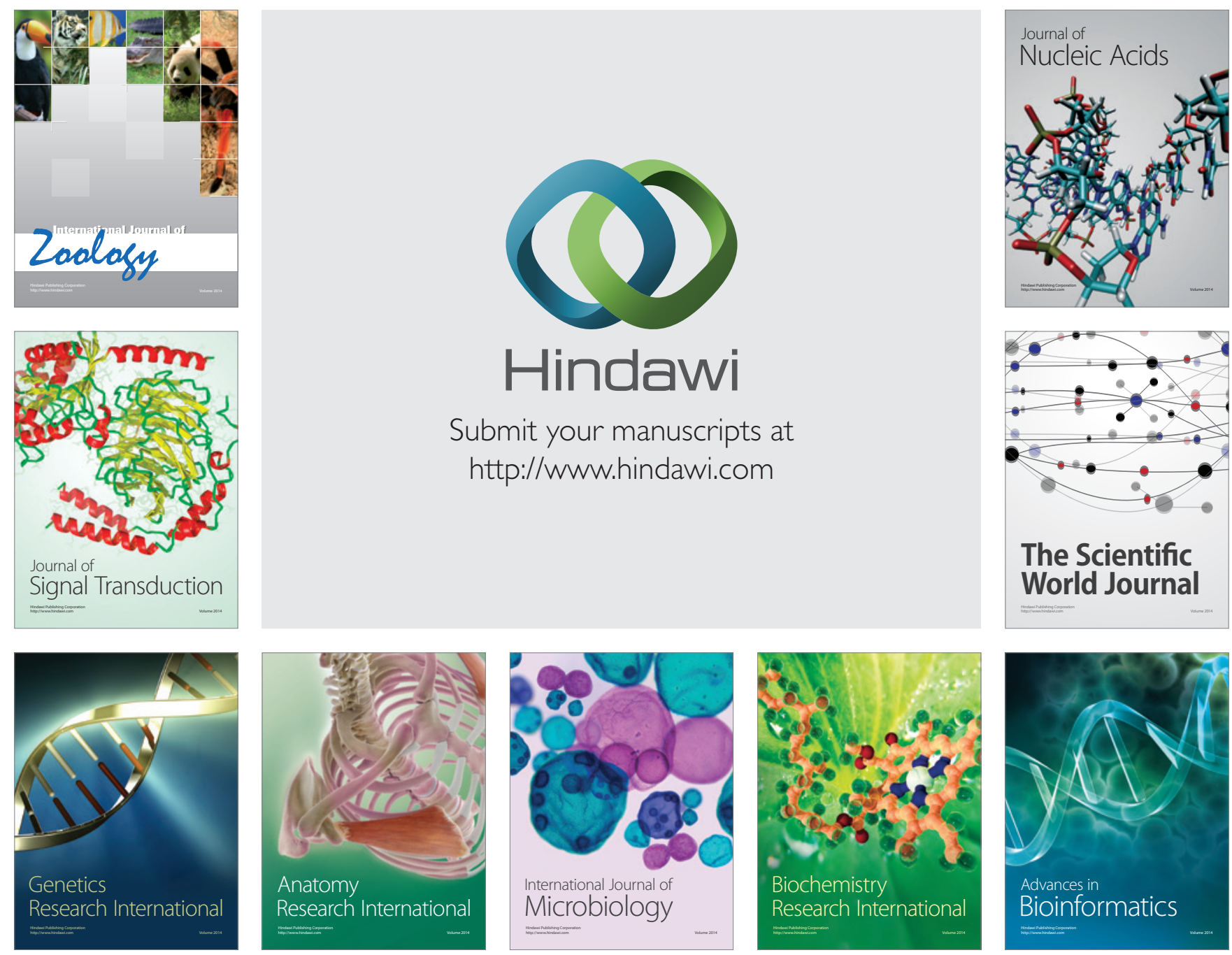

The Scientific World Journal
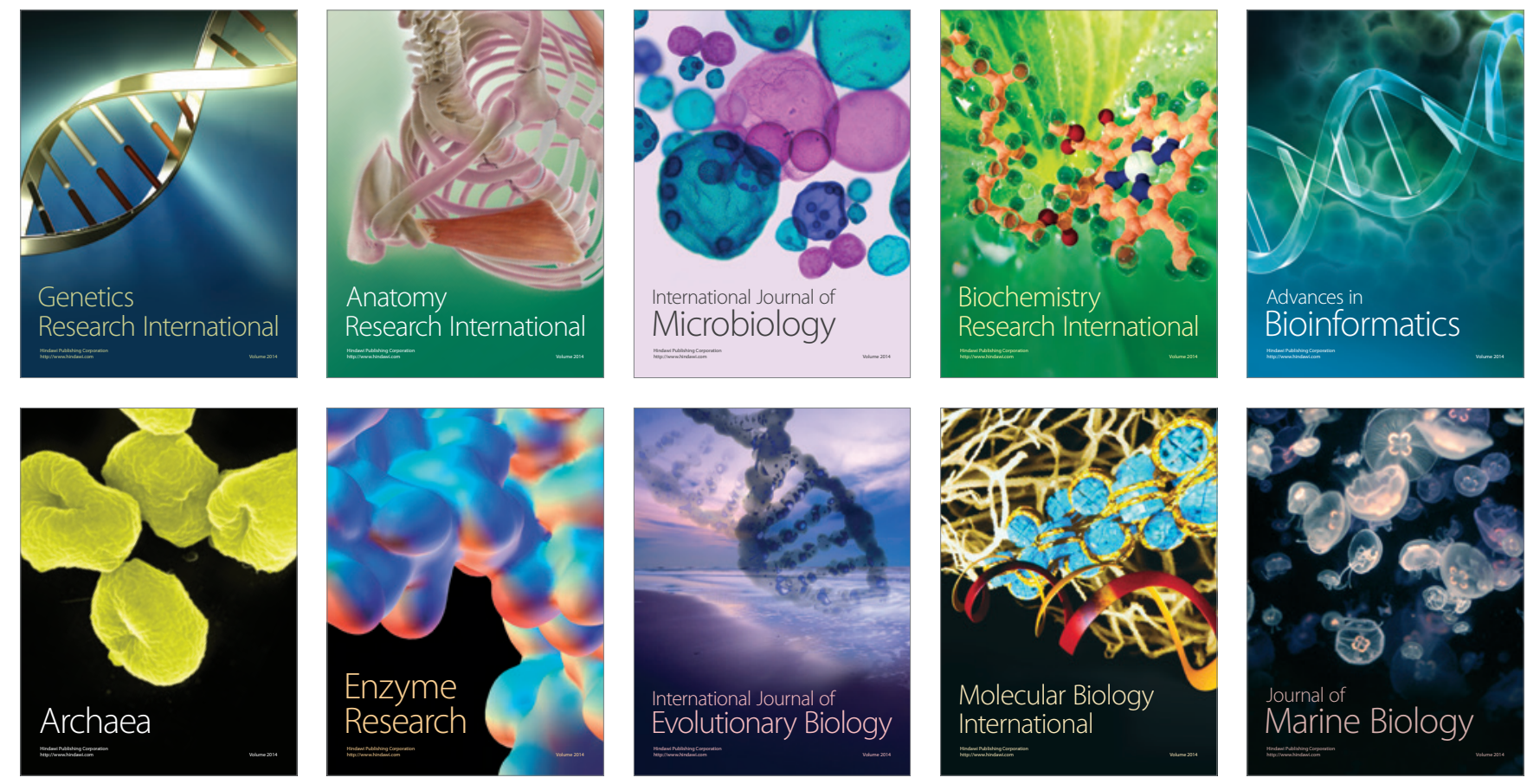